\title{
Adaptations of Coccinella magnifica, a myrmecophilous coccinellid to aggression by wood ants (Formica rufa group). II. Larval behaviour, and ladybird oviposition location ${ }^{1}$
}

\author{
JoHN J. SLOGGETT**and MrChaEL E.N. MAJERUS
}

Department of Genetics, Downing Street, Cambridge, CB2 3EH, U.K.

Key words. Coccinella magnifica, Coccinella septempunctata, Formica rufa, ant-tended aphids, myrmecophily, oviposition

\begin{abstract}
Like adults, larvae of the myrmecophilous ladybird Coccinella magnifica are rarely attacked by Formica rufa ants on foraging trails, but more often attacked on ant-tended aphid colonies. Larvae of the non-myrmecophile Coccinella septempunctata, to which C. magnifica was compared, were more readily attacked by ants in both situations. To avoid or counter ant aggression when foraging for aphids, C. magnifica larvae exhibit three main tactics: they may feed on un- or non-tended aphids; when feeding on tended colonies they often carry prey away, minimising time spent there; and if attacked, they use limited chemical defence. No novel behaviours were found in C. magnifica larvae, not occurring to some extent in C. septempunctata. Coccinella magnifica eggs were laid distant to ant-tended aphids, although closer to un- or non-tended aphids.
\end{abstract}

\section{INTRODUCTION}

Because they are soft-skinned, and thus easily damaged or killed, many ladybird larvae are poorly adapted to coexistence with ants (e.g. Banks, 1962; Bach, 1991). Homoptera form the diet of many ladybird taxa (Hodek, 1996) and a large prey resource is potentially available to such ladybirds in the form of Homoptera tended by ants. However, the aggressive defence of tended Homoptera by attendant ants exerts a strong deterrent effect on predatory ladybirds (e.g. Jiggins et al., 1993). Ovipositing ladybird females are likely to avoid colonies of ant-tended Homoptera, because of the risk of attack (Banks \& Macaulay, 1967; J.J. Sloggett, unpub. data), and larvae encountering ant-tended colonies can be attacked and driven from the colony, suffering possible injury or death in the process (e.g. Banks, 1962; Bradley, 1973; Vinson \& Scarborough, 1989). Additionally, some predatory ant species also take ladybirds and their larvae as prey (e.g. Mariau \& Julia, 1977; Sloggett et al., 1999).

However, the larvae of some ladybird taxa have circumvented the problems posed by ants. Some taxa, which encounter ants at times, possess defensive spines or waxy coverings (Richards, 1980; Völk1 \& Vohland, 1996). Furthermore, a few specialist myrmecophiles have evolved within the Coccinellidae (Sloggett, 1998). Mostly these appear to be larval myrmecophiles, since either the adult has not been recorded with ants, or is known to be attacked by them (e.g. Silvestri, 1903; Wheeler, 1911; Harris, 1921; Pope \& Lawrence, 1990; Völkl, 1995). In these cases slow, cautious movement (Völkl, 1995), a waxy covering (Silvestri, 1903; Wheeler, 1911; Harris, 1921), flattened shape (Pope \& Lawrence, 1990; Völk1,
1995) or chemical mimicry of Homoptera (Oczenascheck, 1997) are known or likely important adaptations of the larvae to circumvent or counter ant aggression. The effectiveness of such adaptations is testified to by the existence of two species believed to predate ants, rather than Homoptera (Harris, 1921; Pope \& Lawrence, 1990).

Coccinella magnifica Redtenbacher $(=C$. distincta Faldermann) is an aphidophagous myrmecophile associated with members of the Formica rufa group and closely allied species, at least in northwestern Europe (see Sloggett et al., 2002). Adults and larvae of this species are recorded feeding on ant-tended aphids, although also sometimes on untended or non-tended aphids (Donisthorpe, 1919-1920; Pontin, 1959; Godeau, 1997; Sloggett et al., 2002). Coccinella magnifica is unusual amongst myrmecophilous coccinellids in a number of respects. First, all life history stages of this aphidophagous species co-occur with ants (Donisthorpe, 1919-1920; J.J. Sloggett, pers. obs.). Second, C. magnifica is the only known myrmecophilous species in the subfamily Coccinellinae. Its larvae are typical of this group, possessing no waxy covering or other obvious morphological adaptation to ants. In fact they are similar to the larvae of other nonmyrmecophilous Coccinella species, its close relatives.

Formica rufa group ants apparently behave aggressively to ladybirds and their larvae both on and off their colonies of tended aphids (review in Sloggett \& Majerus, 2000). Observations in both the laboratory and field have indicated that, although the larvae of $C$. magnifica are sometimes antennated or palpated by $F$. rufa group ants, they are rarely attacked by them, unlike the larvae of other ladybird species (Donisthorpe, 1919-1920; Majerus, 1989; Manica, 1996; Godeau, 1997). Arnold et

\footnotetext{
* Corresponding author. Current address. Lehrstuhl für Tierökologie I, Universität Bayreuth, PO Box 101251, D-95440 Bayreuth, Germany; tel: +49 (0)921 552 409; fax:+49 (0)921 552 784; e-mail: john.sloggett@uni-bayreuth.de
}

${ }^{1}$ Part I: J. Insect Behav. 11: 889-904 (1998). 
al. (unpublished, see Majerus, 1994, p. 151) have observed that $C$. magnifica larvae placed on colonies of Aphis fabae Scopoli tended by the ant Lasius niger (L.) are attacked by the ants, but the larvae ignore these attacks, continuing to feed and behave normally. Coccinella magnifica is not associated with $L$. niger naturally (Sloggett et al., 2002).

Previous work has shown that the likelihood of Formica rufa L. ant attack on adult C. magnifica is contextdependent: whilst $C$. magnifica adults are infrequently attacked on ant foraging trails, where they frequently occur, they are often attacked when on colonies of anttended aphids. As a consequence adult C. magnifica often resort to a combination of physical and behavioural defence when predating ant-tended aphids (Sloggett et al., 1998). In this paper it is demonstrated that the probability of $F$. rufa attack on larvae is also context-dependent. We consider how C. magnifica larvae successfully forage and circumvent the problem of ant aggression on colonies of tended aphids. This presents a much greater risk to the soft-bodied larva than to physically well-defended adult. We also address how the aggression of aphid-tending $F$. rufa could influence spatial aspects of adult $C$. magnifica oviposition.

In much of this work, C. magnifica larvae are compared to those of its congener Coccinella septempunctata L. The two species are known to be closely related on the basis of both morphology and DNA sequence data (Iablokoff-Khnzorian, 1982; G.D.D. Hurst, J.H. Gvd. Schulenburg \& J.J. Sloggett, unpub. data) and are ecologically similar in a number of respects (Sloggett et al., 1998,2002 ). However C. septempunctata is not a myrmecophile, although the adults of this species will sometimes visit colonies of ant-tended aphids when prey is scarce in late summer (Sloggett \& Majerus, 2000). Coccinella septempunctata, therefore, is a good phylogenetically controlled model for the ancestor of C. magnifica before myrmecophily evolved, and has been used as such in a number of earlier studies (see Sloggett, 1998; Sloggett et al., 1998; Sloggett \& Majerus, 2000).

\section{MATERIALS AND METHODS}

\section{General considerations}

The experiments and observations described here were carried out at Oxshott Heath, Surrey England. Additional observations on the location of eggs and larvae were carried out at Esher Common, some one mile distant from Oxshott Heath. General descriptions of the field sites are given by Sloggett et al. (1998). The ant Formica rufa is common at both sites.

The majority of work was carried out between April and July of 1998, with a few replicates of experiments on larval behaviour on ant-tended aphid colonies being carried out in June 1999 (see below for details). During spring and early summer, $C$. magnifica eggs and larvae are commonly found at the study sites associated with $F$. rufa. Coccinella septempunctata larvae are not found in the vicinity of $F$. rufa nests, although they are to be found on herbaceous plants nearby (see Sloggett \& Majerus, 2000).

Experiments using ant-tended aphid colonies were conducted on Scots pine, Pinus sylvestris L., using ant-tended Cinara aphid colonies. Two Cinara species occur at Oxshott Heath on
P. sylvestris: Cinara pilosa (Zetterstedt) (often described as $C$. pinea (Mordwilko) by many British authors: C. I. Carter, personal communication), from April to July, and Cinara pini (L.), from April to October. Of the two species, C. pini is the more intensively tended by ants, whereas C. pilosa tends to form looser aggregations, which are sporadically attended (see Völkl \& Kroupa, 1997, on C. pini and C. pinea). The Cinara species used in individual trials were not recorded, but the majority of colonies used, if not all, were likely to be $C$. pini, since this forms better, more easily defined colonies which are easier to work with

Coccinella magnifica larvae used in experiments were laboratory reared from ovipositing C. magnifica adults, or from egg clutches, collected at Oxshott Heath. They were fed on a diet of pea aphids, Acyrthosiphon pisum (Harris), initially in $90 \mathrm{~mm}$ Petri dishes for each clutch of larvae, later in $140 \mathrm{~mm}$ Petri dishes for up to eight larvae. There is no difference in the behaviour of $F$. rufa towards naturally occurring and laboratory bred C. magnifica, on ant trails at least (Manica, 1996). Coccinella septempunctata larvae were a mixture of laboratory bred individuals, reared in the same way as $C$. magnifica, and individuals collected near the field sites and at Mickleham, near Dorking, in Surrey. All experiments used final (fourth) instar larvae.

Experiments comparing $C$. magnifica larvae with $C$. septempunctata larvae, and the effect of context (ant-tended aphid colonies vs. ant trails) were conducted using matched replicates, testing both a $C$. magnifica and a C. septempunctata larva on the same trail or ant colony consecutively. Additionally aphid colonies were tended by ants from the same nest as the ants on the foraging trails for each matched replicate in the experiment on context dependence. The order of trials within a replicate was randomised. Within matched replicates on the same $F$. rufatended aphid colony, a gap of at least 15 minutes was left between trials. Each larva used in experimental replicates originated from a different female or egg clutch, although larvae in different treatments within a replicate were usually related. Thus pseudoreplication through the use of related individual larvae was avoided.

Formica rufa aggression toward $C$. magnifica and $C$. septempunctata larvae in the presence and absence of ant-tended aphids

To compare the likelihood of attack by $F$. rufa on C. magnifica and $C$. septempunctata larvae on foraging trails and colonies of ant-tended aphids, the same method was used as that previously used for adults of the two species (Sloggett et al., 1998). Larvae were released individually, either onto an $F$. rufa foraging trail, on the ground, or near a colony of tended aphids. The number of $F$. rufa workers encountering each larva until it was attacked was recorded and a score allotted on that basis. Thus a score of five would indicate that the first four ants that encountered the larva did not attack it and the fifth did. If a larva was not attacked after 10 encounters it was allotted a score of $>10$ or unattacked. A larva was considered attacked if an ant attempted to bite it or spray it with formic acid. Larvae that left the trail or aphid colony before they had been attacked or 10 encounters were recorded were returned to the trail or aphids. A total of 15 replicates were carried out between April and July 1998.

Some larval behaviour on ant trails was also recorded, as was the behaviour of some wild C. magnifica larvae observed. 
(a) Formica rufa foraging trails

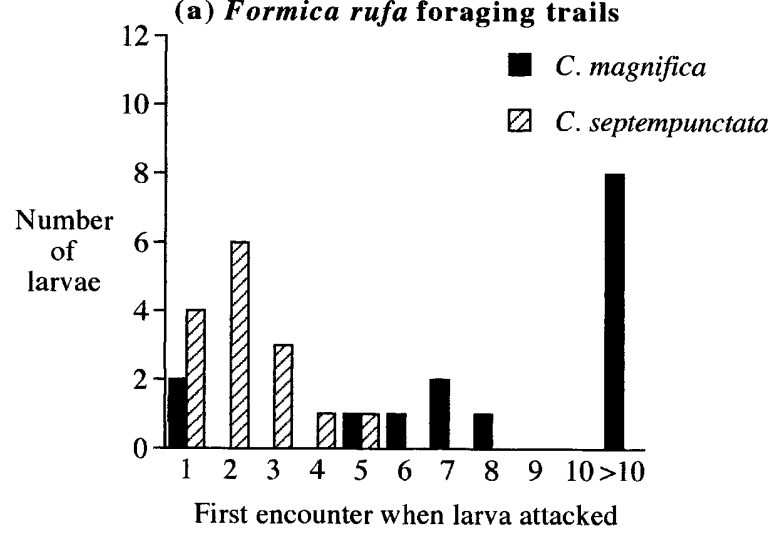

(b) Formica rufa-tended aphid colonies

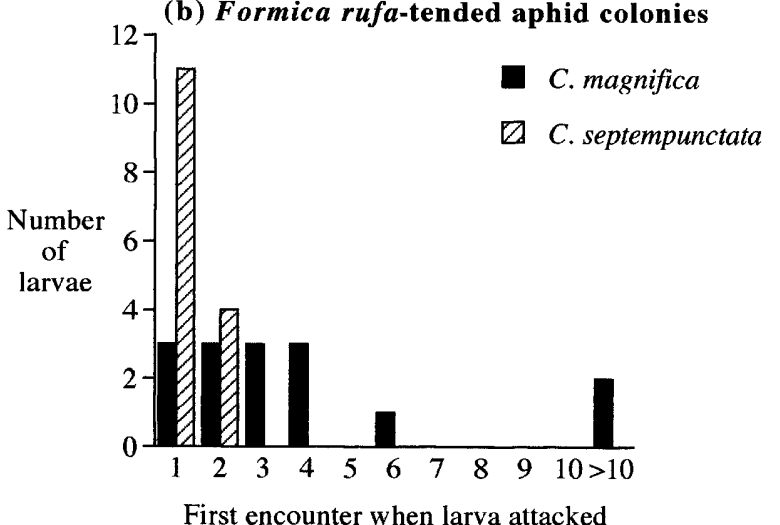

Fig. 1. Frequency distribution of $F$. rufa attacks on the larvae of $C$. magnifica and C. septempunctata on foraging trails and tended aphid colonies.

Behaviour of ants and larvae of $C$. magnifica and $C$. septempunctata on ant-tended aphid colonies

Larvae that had been starved from the early morning $(>3$ hours) were placed near individual colonies of $F$. rufa-tended aphids and allowed to walk onto the colony. Each individual was recorded as attacked or unattacked by the ants whilst on the colony. A larva was only recorded as unattacked if it was not attacked by any of the ants it encountered whilst on the colony, or if it failed to encounter any ants. Larvae were not returned to the aphid colony if they failed to encounter ants, unlike the adults of Sloggett et al. (1998).

The number of aphids eaten by each larva was recorded, as was other larval behaviour including chemical defence. The time larvae spent on the colony, up to a maximum of 30 minutes was also recorded. Nineteen replicates were carried out between April and July 1998; a further three were carried out in June 1999.

\section{Field observations on the occurrence of $C$. magnifica eggs and larvae}

During the experiments, records were kept of the occurrence of naturally occurring $C$. magnifica egg clutches and larvae at Oxshott Heath and Esher Common. The distance of each $C$. magnifica egg clutch from the nearest colony of $F$. rufa-tended aphids and from the nearest untended/non-tended aphids was measured. Measurements were to the nearest centimetre. The distribution of larvae in relation to ant trails and colonies of anttended aphids was also recorded.

\section{Analysis and reporting of results}

Ordinal data was analysed using non-parametric tests (Wilcoxon Signed Ranks Test for Paired Samples and the MannWhitney Test: Zar, 1999), due to its non-normal distribution. Tests were all two-tailed. Frequency data (as $2 \times 2$ tables) was analysed using chi-square tests, using the Yates' correction for continuity: data was considered suitable for chi-square analysis since the mean expected value of all tables was greater than 6 (Zar, 1999).

Some observations for larvae similar to those previously analysed fully for adults (Sloggett et al. 1998) are reported here anecdotally, specifically the behaviour of larvae on ant trails and some aspects of larval and ant behaviour on colonies of aphids. In the case of larvae on ant trails it was difficult to make a large number of semi-independent observations after larvae had been attacked by ants and reflex bled, making an analysis similar to that of Sloggett et al. (1998) impossible. On colonies of tended aphids, ant densities were much lower than when adult ladybirds were studied and attacks on larvae were often of a sporadic nature, unlike those on the adults (J.J. Sloggett, personal observation). This makes statistical analysis of some aspects of behaviour highly problematic (for example, larval escape behaviour in the face of ant attack).

\section{RESULTS}

Formica rufa aggression toward $C$. magnifica and $C$. septempunctata larvae in the presence and absence of ant-tended aphids

Formica rufa workers attacked C. magnifica larvae significantly less than they attacked $C$. septempunctata larvae both on ant trails and on colonies of ant-tended aphids (Fig. 1. Two-tailed Wilcoxon Signed Ranks Test, counting a score of $>10$ as 11 : trails $-\mathrm{n}=15$ non-ties, $T^{+}$ $=117, T^{-}=3, P<0.001$; tended aphids $-\mathrm{n}=11$ non-ties +4 ties, $\left.T^{+}=66, T^{-}=0, P<0.001\right)$.

However, $F$. rufa aggression towards $C$. magnifica larvae was much greater on colonies of ant-tended aphids than on ant trails (Fig. 1. Two-tailed Wilcoxon test: $C$. magnifica: $\mathrm{n}=12$ non-ties +3 ties, $T^{+}=74, T^{\llcorner}=4, P<$ $0.005)$. The same was also true for $C$. septempunctata larvae $\left(\mathrm{n}=9\right.$ non-ties +6 ties, $\left.T^{+}=45, T^{-}=0, P=0.005\right)$.

Observations of the behaviour of ladybird larvae on ant foraging trails

On trails, F. rufa workers often displayed no visible reaction to a $C$. magnifica larva or sometimes tapped it with their antennae. Many $C$. magnifica larvae remained motionless for long periods on ant foraging trails. When moving, $C$. magnifica larvae were, at times, observed to stop on encountering ants, as do $C$. magnifica adults (Sloggett et al., 1998). Coccinella septempunctata larvae were rapidly attacked. In response, they frequently produced copious quantities of reflex blood, the characteristic chemical defence of ladybird adults and larvae (Daloze et al., 1995). To some extent reflex bleeding deterred ants from further attacks, although frequently $C$. septempunctata larvae were surrounded and ultimately carried off by the ants, presumably serving as prey (see Sloggett et al. 1999). At times moving C. septempunctata larvae stopped in response to an encounter with an ant, like C. magnifica larvae. 
Table 1. Comparison of C. magnifica and C. septempunctata interactions with $F$. rufa on colonies of ant-tended aphids.

\begin{tabular}{|c|c|c|c|}
\hline & $\begin{array}{l}\text { Coccinella } \\
\text { magnifica }\end{array}$ & $\begin{array}{c}\text { Coccinella } \\
\text { septempunctata }\end{array}$ & Statistical test \\
\hline \multicolumn{4}{|l|}{$N=\mathbf{2 2}$ paired replicates } \\
\hline \multicolumn{4}{|l|}{ Probability of encounter and attack by ants } \\
\hline Larva did not encounter ants & 6 & 2 & $X^{2}=1.37,1 \mathrm{df}, \mathrm{NS}^{\mathrm{a}}$ \\
\hline Larva did encounter ants, but was not attacked & 8 & 2 & $X^{2}=5.24,1 \mathrm{df}, P<0.025^{\mathrm{a}, \mathrm{b}}$ \\
\hline Total larvae unattacked & 14 & 4 & $X^{2}=7.62,1 \mathrm{df}, P<0.01^{\mathrm{a}}$ \\
\hline Larvae attacked & 8 & 18 & \\
\hline \multicolumn{4}{|l|}{ Probability of injury or death to larva } \\
\hline Larva seized & 1 & 3 & $X^{2}=0.27,1 \mathrm{df}, \mathrm{NS}^{\mathrm{c}}$ \\
\hline Larva dragged from colony & 0 & 1 & $c^{2}=0,1 \mathrm{df}, \mathrm{NS}^{\mathrm{c}}$ \\
\hline \multicolumn{4}{|l|}{ Larval feeding behaviour on colony } \\
\hline Feeding on tended aphids & 15 & 14 & $x^{2}=0,1 \mathrm{df}, \mathrm{NS}$ \\
\hline Number of aphids eaten (mean $\pm \mathrm{SE}$ ) & $1.64 \pm 0.35$ & $1.00 \pm 0.23$ & $\begin{array}{l}\text { Wilcoxon Signed Ranks Test: } \\
\mathrm{n}=15 \text { nonties }+7 \text { ties, } T^{+}=90 \\
T^{-}=30,0.10>P>0.05\end{array}$ \\
\hline Carrying an aphid & 11 & 1 & $X^{2}=10.49,1 \mathrm{df}, P<0.002^{\mathrm{d}}$ \\
\hline \multicolumn{4}{|l|}{ Larval chemical defence } \\
\hline Visible reflex bleeding & 2 & 15 & $X^{2}=5.95,1 \mathrm{df}, P<0.02^{\mathrm{e}}$ \\
\hline $\begin{array}{l}\text { No visible reflex bleeding, } \\
\text { but ant wiping mouthparts }\end{array}$ & 3 & 0 & \\
\hline Total chemical defence & 5 & 15 & $X^{2}=0.43,1 \mathrm{df}, \mathrm{NS}^{\mathrm{e}}$ \\
\hline Length of time on colony (medians) ${ }^{\mathrm{f}}$ & $218 \mathrm{sec}$ & $242 \mathrm{sec}$ & $\begin{array}{c}\text { Wilcoxon Signed Ranks Test: } \\
\mathrm{n}=21 \text { non-ties, } T^{+}=132, T^{-}=99, \text { NS }\end{array}$ \\
\hline
\end{tabular}

${ }^{a}$ Three independent chi-square tests have been used to analyse these data, since ant behaviour and larval behaviour effects may be independent.

bata in which larvae did not encounter ants have been excluded from the chi-square test, thus sample sizes are 16 for $C$. magnifica and 20 for C. septempunctata.

${ }^{\circ}$ Chi-square tests are based on the total sample size (i.e. $n=22$ for both species), rather than on the number of individuals attacked. ${ }^{2}$ Chi-square tests are based on the number of individuals which fed, thus the sample sizes are 15 individuals for $C$. magnifica and 14 individuals for C. septempunctata.

${ }^{e}$ Chi-square tests are based on the number of larvae attacked, thus the sample sizes are 8 for C. magnifica and 18 for C. septempunctata.

${ }^{\mathrm{f}} n=21$ for both species, as one paired replicate where a $C$. septempunctata was captured by the ants has been excluded. Time does not include aphid consumption if the larva carried the aphid from the colony and ate it elsewhere.

Behaviour of ants and larvae of $\boldsymbol{C}$. magnifica and $\boldsymbol{C}$. septempunctata on ant-tended aphid colonies

Ant and larval behaviour on tended aphid colonies is summarised and analysed in Table 1. Coccinella magnifica larvae were significantly less likely to be attacked by $F$. rufa than the larvae of $C$. septempunctata during a visit to a colony of tended aphids. This effect arose due to two factors. First, fewer C. magnifica larvae were directly encountered by ants during visits to aphid colonies, although the effect is not significant. Second, when $C$. magnifica were encountered by ants during a visit to an aphid colony, fewer were attacked.

In general C. magnifica larvae appeared to move more slowly than those of $C$. septempunctata. Both $C$. magnifica and $C$. septempunctata larvae readily fed on tended aphids, although their mode of feeding was somewhat different. Coccinella septempunctata larvae began feeding rapidly on encountering aphids and would often continue to feed at the site until attacked. On the other hand, $C$. magnifica larvae frequently picked up aphids and carried them in their jaws. Typically, a larva would seize an aphid at the edge of a colony and slowly back away from the colony along the branch or a pine needle to a distance of several centimetres. In two cases of 11 larvae moved forward with an aphid, and in one case a larva that had been backing away with an aphid, dropped from the branch with it on being attacked by an ant. This behaviour was observed when ants were both present and absent from the immediate vicinity of larvae. Aphidcarrying behaviour similar to that of $C$. magnifica was only observed for $C$. septempunctata once, and in this case the larva may have been endeavouring to maintain a firm grip on the substrate rather than trying to leave the aphid colony. The difference in the occurrence of this behaviour in the two species was highly significant.

No significant differences were found in the length of time larvae of the two species spent on the aphid colonies. This probably arises for several reasons. Coccinella septempunctata larvae were rapidly expelled from the colony when encountered by $F$. rufa and C. magnifica larvae 
minimise the time spent on the colony by carrying aphids away from the colony to eat. Furthermore both species often fed for some while before encountering ants, and this additional time period, present for both species, acts to further reduce any differences between them in the data.

There was a non-significant trend for C. magnifica larvae to consume more aphids than $C$. septempunctata. It is worth noting that the data probably underestimate the difference, since an aphid was counted as eaten when a larva began eating it, rather than when it was entirely consumed. Coccinella septempunctata larvae were frequently interrupted, and deterred from further feeding by ant attack, whereas this was rarely the case for C. magnifica.

Under ant attack, C. septempunctata larvae usually produced copious quantities of reflex blood $(83 \%$ of attacked larvae). In contrast, attacked C. magnifica larvae reflex bled to deter ants visibly on two occasions $(25 \%)$ and the quantity produced was visibly far less than that of C. septempunctata larvae. However, in three further cases ants were observed wiping their mouthparts, for up to five minutes after attacking C. magnifica larvae, without any visible reflex bleeding. It is unclear whether they were responding to minute quantities of reflex blood not visible to the observer, or whether the larva is generally distasteful to the ant. The number of cases of reflex bleeding visible to the observer is significantly higher in C. septempunctata: If the extra C. magnifica cases, where reflex bleeding may have occurred but was not visible, are included the difference between the two species is not significant.

In general, for both C. magnifica and C. septempunctata, chemical defence appeared to be a very effective deterrent. Only three $C$. septempunctata larvae were seized by the ants and of these only one failed to escape and was carried from the colony by the ants. Ants were clearly repelled by $C$. magnifica reflex bleeding: Only single $C$. magnifica larva was seized by an $F$. rufa worker. This individual did not reflex bleed and no mouthpart wiping was observed on the part of the ant afterwards, although the larva escaped.

After reflex bleeding, C. septempunctata larvae typically ran from the aphid colony, to evade the ants. Coccinella magnifica larvae also sometimes ran from the colony, but in several cases ant attacks were abandoned and the larvae remained where they were. On occasions larvae of both species dropped from the branch after an attack. There did not appear to be any differences in the tendencies of the two species to run or drop, unlike those reported for the adults under ant attack (Sloggett et al., 1998). Running was most common.

\section{Field observations on the occurrence of eggs and larvae}

Seven clutches of $C$. magnifica eggs were discovered in the field in 1998. Three were found at Oxshott Heath on Scots pine. Ant tended aphid colonies here consisted of the two Cinara species, C. pilosa and C. pini, and untended aphids were $C$. pilosa without ants and the nontended Schizolachnus pineti (F.). Four clutches were found at Esher Common on spruce (Picea sp.) with the tended aphid Cinara piceicola Cholodkovsky and nontended aphid Elatobium abietum (Walker). At both sites all egg clutches were found to be closer to un- or nontended aphids (mean $\pm \mathrm{SE}, 4.4 \pm 1.8 \mathrm{~cm}$ ) than to anttended aphid colonies $(43.3 \pm 8.4 \mathrm{~cm}$ ) (Two-tailed Wilcoxon Signed Ranks Test of egg clutch distances from tended $v s$. un-/non-tended aphids: $\mathrm{n}=7$ non-ties, $T^{+}=28$, $T^{\llcorner}=0, P<0.02$ ).

In 1998, a total of 76 larvae of all instars were observed at Oxshott Heath and Esher Common. Of 49 larvae observed at Oxshott Heath, 31 (63\%: second to fourth instar) were observed apparently foraging on $F$. rufa trails or nearby low growing vegetation in the absence of anttended aphids. At Oxshott Heath, C. pilosa aphids are often also observed on ant trails, presumably having fallen from overhanging branches of Scots pine (see Kloft, 1953) and a C. magnifica larva was observed feeding on such prey on an ant trail. Other non-tended aphids occur on surrounding herbaceous plants here (J.J. Sloggett, personal observation). Eighteen larvae (37\%: first to fourth instar) were observed either on, or in the near vicinity of colonies of ant-tended aphids: 13 were observed on Scots pine; some of these may have been foraging on untended $C$. pilosa or the non-tended $S$. pineti. The other five were observed on gorse, Ulex europeus L., associated with Aphis ulicis Walker, tended by F. rufa, and Myrmica ruginodis Nylander. Coccinella magnifica larvae, as well as adults, were observed associated with colonies tended by both ants, although C. magnifica is not a regular associate of Myrmica species.

At Esher Common, spruce was examined again, later in the season, after the discovery of egg clutches there. In excess of 27 larvae were present on a single spruce tree: The non-tended E. abietum was not recorded at this time; therefore it appears these larvae were feeding on the $F$. rufa-tended C. piceicola, which was present. No C. magnifica larvae were found on ant trails. The aphid $C$. pilosa was not present on ant trails at this site.

\section{DISCUSSION}

The problems of ant aggression faced by C. magnifica larvae appear to be very similar to those faced by adult $C$. magnifica (Sloggett et al., 1998). That is, although ants rarely attack $C$. magnifica larvae in the absence of tended aphids, they are much more likely to attack the larvae on colonies of tended aphids. This is probably because the ants tending colonies of aphids display ownership behaviour (Way, 1963), perhaps responding to a change in aphid behaviour in the presence of an intruder (Nault et al., 1976), in addition to or in place of their predatory instincts exhibited away from aphid colonies (Way, 1963; Sloggett et al., 1999).

Coccinella magnifica larvae, like the adults, probably possess some form of chemical inhibition of $F$. rufa aggression, based on extreme repellence (Sloggett, 1998; J.J. Sloggett, unpublished data; see also Dixon, 2000, p. 30 , and below). This provides an extremely effective counter to predatory ant aggression when tended aphids 
are not present, for example on ant foraging trails. However, as for the adult, it is less effective on colonies of ant-tended aphids. It is clearly not the case that C. magnifica larvae are not attacked by ants whereas the adults are, as has been previously suggested (Godeau \& Hemptinne, cited by Dixon, 2000, pp. 105-106). Larvae, like adults, are infrequently attacked by $F$. rufa on trails, and more often attacked on colonies of $F$. rufa-tended aphids.

Faced with potential attack on colonies of $F$. rufatended aphids, how do the soft-bodied larvae of $C$. magnifica forage successfully then? The solution appears to be threefold: $C$. magnifica larvae may simply not forage on ant-tended aphids; if they do they minimise the time spent on the aphid colony; and if they are attacked they use limited chemical defence to deter the attack.

Often C. magnifica larvae do not forage on ant-tended aphids, but on untended or non-tended aphids, thus avoiding the heightened aggression of aphid-tending $F$. rufa. This is indicated by the occurrence at Oxshott Heath of numbers of larvae on or near ant-foraging trails, probably feeding on stray $C$. pilosa and non-tended aphids on herbaceous plants. At Esher Common, where unlike Oxshott Heath, there were no stray untended $C$. pilosa, larvae were not found on ant trails. This suggests that the occurrence of larvae on trails is not accidental, for example as a consequence of falling from vegetation. Furthermore, the boundary between aphids that are anttended and those that are not is not invariable, and for much of spring and early summer there is an excess of available facultatively tended aphids, such as C. pilosa, from which $F$. rufa group ants obtain honeydew (Wellenstein, 1952; J.J. Sloggett, personal observation). As a consequence many colonies of aphids are only sporadically attended by ants. Coccinella magnifica larvae undoubtedly exploit such colonies.

The larvae also clearly sometimes feed on well-tended aphid colonies, such as those of $C$. pini and $C$. piceicola. When feeding on ant-tended aphids two strategies of $C$. magnifica larvae are apparent. First, C. magnifica larvae exhibit a characteristic aphid carrying behaviour, typically picking up an aphid from the edge of colony of tended aphids and backing away from the colony with it. This behaviour serves to minimise the time in which the larva is exposed to aggressive aphid-tending ants. If all else fails, and a larva is attacked, it can use chemical defence. It appears that C. magnifica larvae have, however, minimised the cost of chemical defence. Unlike $C$. septempunctata larvae, those of C. magnifica do not copiously reflex bleed, losing large quantities of liquid and defensive alkaloid. Very little reflex blood appears to be produced by $C$. magnifica larvae in response to ant attack: In some cases none was visible to the observer. Perhaps C. magnifica larvae often rely on their characteristic repellent counter to ant aggression as a protection and do not reflex bleed at all. Certainly some role is played by this in minimising aphid-tending $F$. rufa attacks on $C$. magnifica larvae, since although the larvae are attacked, it is at a lower frequency than C. septempunctata larvae.
It is also perhaps noteworthy that, rather than coccinelline and precoccinelline, alkaloids characteristic of the chemical defence of other Coccinella species (Daloze et al., 1995; King \& Meinwald, 1996), the major alkaloid of C. magnifica is hippodamine (Lognay, cited by Dixon, 2000, p. 30), which is present in only minor quantities in C. septempunctata (Daloze et al., 1995). The full significance of this finding in relation to C. magnifica's association with ants remains to be assessed, although preliminary experiments indicate that C. magnifica larval chemical defences are more repellent to ants than those of C. septempunctata (J.J. Sloggett unpublished data).

Relatively slow movement also undoubtedly plays a part in avoidance of ant attack by $C$. magnifica larvae. It has been suggested that $C$. magnifica larvae have slightly shorter legs than C. septempunctata (Dixon, 2000, p. 69). This seems a likely adaptation against capture by ants on colonies of ant-tended aphids. Unlike some other myrmecophilous coccinellid larvae, such as Platynaspis luteorubra Goeze, which remain in very close association with ant-tended aphid colonies (Völk1, 1995), the highly mobile larvae of $C$. magnifica move readily between aphid colonies: thus their legs are not shorter due to limited use.

As with the adult ladybirds, there appear to be no behaviours unique to C. magnifica larvae. Most C. magnifica behaviour was observed at least once in C. septempunctata larvae. In its evolving myrmecophily, the expression of certain behaviours of C. magnifica, such as aphid carrying, have been enhanced and whereas the expression of others, such as reflex bleeding, have been reduced. Such modifications of behavioural expression are undoubtedly far more common than the evolution of entirely novel behaviours. The case of C. magnifica and C. septempunctata bears noteworthy similarities to the case of the myrmecophilous chrysopid Chrysopa slossonae Banks and its non-myrmecophilous sibling species Chrysopa quadripunctata Burmeister, in this respect (see Milbrath et al., 1993).

Feeding on sporadically-tended, untended or nontended aphids is also a tactic followed by adult C. magnifica in the spring and early summer. Adult $C$. magnifica have also often been recorded on ant trails (Morris, 1888; Champion, 1903; Donisthorpe, 1919-1920; J.J. Sloggett, personal observation). However ant-tended aphids are of greater importance to adult $C$. magnifica, since these predominate in late summer, after the larvae have metamorphosed. Adult C. magnifica are better protected by their tougher cuticle, and therefore are in less danger from ant attack than the soft-bodied larvae. Furthermore, adults typically use purely physical and behavioural defence under ant attack and do not have to resort to chemical defences, which need replacing after use (Sloggett et al., 1998). Thus feeding on ant-tended aphids is undoubtedly less costly for the adults than for the larvae of C. magnifica.

From the data presented here, it appears that female $C$. magnifica oviposit close to untended or non-tended aphids, but distant from ant-tended aphids. It had been 
previously been suggested that $C$. magnifica oviposits at a distance from aphid colonies, although it remained unclear whether un- or non-tended aphids were considered (Godeau \& Hemptinne, cited by Dixon, 2000, p. 106). Although the relatively clumped distribution of anttended aphids relative to non-tended species makes the finding that $C$. magnifica egg clutches are laid closer to un- or non-tended aphids intrinsically likely, even were clutch distributions random, it does seem likely that female C. magnifica do oviposit away from colonies of ant-tended aphids to avoid ant aggression towards themselves or their eggs. In the absence of nearby tended aphids C. magnifica eggs are rarely attacked by $F$. rufa group ants, like C. magnifica adults and larvae (Godeau, 1997; J.J. Sloggett, unpublished data). However, it is not known whether $F$. rufa would attack C. magnifica eggs occurring in the immediate vicinity of tended aphids, although this seems probable. The finding that eggs are frequently laid near to un- or non-tended aphids is consistent with the view that $C$. magnifica larvae often avoid ant aggression by not feeding on ant-tended aphids. This seems particularly likely for neonate larvae, which will initially encounter un- or non-tended aphids in their search for food. The first instar larvae of C. magnifica are arguably at greatest risk from aggression by aphid tending ants, due to their very small size.

ACKNOWLEDGEMENTS. We wish to express our thanks to the Elmbridge Borough Council and the Elmbridge Commons Ranger, David Page, for permission to carry out this work at the field sites, and to Mary Webberley for her assistance in collecting adult ladybirds for breeding. We also wish to thank the BBSRC, for a Ph.D. studentship to John Sloggett (1994-1997), during which time many of the ideas for this work were formulated, and preliminary work was carried out.

\section{REFERENCES}

BACH C.E. 1991: Direct and indirect interactions between ants (Pheidole megacephala), scales (Coccus viridis) and plants (Pluchea indica). Oecologia 87: 233-239.

BANKS C.J. 1962: Effects of the ant Lasius niger (L.) on insects preying on small populations of Aphis fabae Scop. on bean plants. Ann. Appl. Biol. 50: 669-679.

BanKs C.J. \& MacaUlay E.D.M. 1967: Effects of Aphis fabae Scop. and of its attendant ants and insect predators on yields of field beans (Vicia faba L.). Ann. Appl. Biol. 60: 445-453.

Bradley G.A. 1973: Effect of Formica obscuripes (Hymenoptera: Formicidae) on the predator-prey relationship between Hyperaspis congressis (Coleoptera: Coccinellidae) and Toumeyella numismaticum (Homoptera: Coccidae). Can. Entomol. 105: 1113-1118.

Champion G.C. 1903: Coccinella distincta, Fald., \& c., at Woking. Entomol. Mon. Mag. 39: 151-152.

Daloze D., Braekman J.-C. \& Pasteels J.M. 1995: Ladybird defence alkaloids: structural, chemotaxonomic and biosynthetic aspects (Col.: Coccinellidae). Chemoecology 5/6: 173-183.

DixON A.F.G. 2000: Insect Predator-Prey Dynamics: Ladybird Beetles and Biological Control. Cambridge University Press, Cambridge, $257 \mathrm{pp}$.

DONISTHORPE H. 1919-1920: The myrmecophilous lady-bird, Coccinella distincta, Fald., its life-history and association with ants. Entomol. Rec. J. Var. 31: 214-222, 32: 1-3.
Godeau J.-F. 1997: Adaptations à la Cohabitation avec des Fourmis: le cas de Coccinella magnifica Redtenbacher. Unpublished diploma thesis, Faculté Universitaire des Sciences Agronomiques de Gembloux, $41 \mathrm{pp}$.

HARRIS R.H.T.P. 1921: A note on Ortalia pallens Muls. S. Afr. J. Sci. 18: 170-171.

HoDek I. 1996: Food relationships. In: Hodek I. \& Honěk A.: Ecology of Coccinellidae. Kluwer Academic Publishers, Dordrecht, pp. 143-238.

IABLOKOFF-KHNZORIAN S.M. 1982: Les Coccinelles. ColéoptèresCoccinellidae. Tribu Coccinellini des Régions Palearctique et Orientale. Société Nouvelle des Éditions Boubée, Paris, 568 pp.

Jiggins C., Majerus M. \& Gough U. 1993: Ant defence of colonies of Aphis fabae Scopoli (Hemiptera: Aphididae), against predation by ladybirds. Br. J. Entomol. Nat. Hist. 6: 129-137.

King A.G. \& MenNwald M. 1996: Review of the defensive chemistry of coccinellids. Chem. Rev. 96: 1105-1122.

Kloft W. 1953: Waldameisen und Pfanzenläuse. Allgem. Forstz. 8: 529.

MaJerus M.E.N. 1989: Coccinella magnifica (Redtenbacher): a myrmecophilous ladybird. Br. J. Entomol. Nat. Hist. 2: 97-106.

MAJERUS M.E.N. 1994: Ladybirds. New Naturalist series 81, HarperCollins, London, 367 pp.

Manica A. 1996: Ant Adaptations in Coccinella magnifica Larvae. Unpublished undergraduate project report, Department of Genetics, University of Cambridge, $14 \mathrm{pp}$.

MARIAU D. \& JULIA J.F. 1977: Nouvelles rechérches sur la cochenille du cocotier Aspidiotus destructor (Sign.). Oléagineux 32: 217-224.

Milbrath L.R., Tauber M.J. \& Tauber C.A. 1993: Prey specificity in Chrysopa: an interspecific comparison of larval feeding and defensive behaviour. Ecology 74: 1384-1393.

MorRIS C.H. 1888: Coccinella labilis, Muls., attached to the nests of Formica rufa. Entomol. Mon. Mag. 25: 36.

Nault L.R., Montgomery M.E. \& Bowers W.S. 1976: Antaphid associations: role of aphid alarm pheromone. Science 192: $1349-1351$.

OCZENASCHECK C. 1997: Chemische Ökologie der Entwicklungsstadien des Marienkäfers Platynaspis luteorubra Goeze. Unpublished diploma thesis, University of Bayreuth, $101 \mathrm{pp}$.

PontIN A.J. 1959: Some records of predators and parasites adapted to attack aphids attended by ants. Entomol. Mon. Mag. 95: 154-155.

Pope R. D. \& Lawrence J.F. 1990: A review of Scymnodes Blackburn, with a description of a new Australian species and its larva (Coleoptera: Coccinellidae). Syst. Entomol. 15: 241-252.

RicharDS A.M. 1980: Defensive adaptations and behaviour in Scymnodes lividigaster (Coleoptera: Coccinellidae). J. Zool., Lond. 192: 157-168.

SILVESTRI F. 1903: Contribuzioni alla conoscenza dei mirmecofili, I. Osservazioni su alcuni mirmecofili dei dintorni di Portici. Ann. Mus. Zool. R. Univ. Napoli 1: 1-5.

SloGgett J.J. 1998: Interactions Between Coccinellids (Coleoptera) and Ants (Hymenoptera: Formicidae), and the Evolution of Myrmecophily in Coccinella magnifica Redtenbacher. Unpublished Ph.D. thesis, University of Cambridge, 245 pp.

SLoggett J.J. \& MaJerus M.E.N. 2000: Aphid-mediated coexistence of ladybirds (Coleoptera: Coccinellidae) and the wood ant Formica rufa L.: seasonal effects, interspecific variability and the evolution of a coccinellid myrmecophile. Oikos 89: 345-359.

Sloggett J.J., Manica A., Day M.J. \& Majerus M.E.N. 1999: Predation of ladybirds (Coleoptera: Coccinellidae) by wood 
ants, Formica rufa L. (Hymenoptera: Formicidae). Entomologists Gaz. 50: 217-221.

Sloggett J.J., Völkl W., Schulze W., G. v. D. Schulenburg J. H. \& Majerus M.E.N. 2002: The ant-associations and diet of the ladybird Coccinella magnifica (Coleoptera: Coccinellidae). Eur. J. Entomol. 99: 565-569.

Sloggett J.J., Wood R.A. \& Marerus M.E.N. 1998: Adaptations of Coccinella magnifica Redtenbacher, a myrmecophilous coccinellid to aggression by wood ants (Formica rufa group). I. Adult behavioural adaptation, its ecological context and evolution. J. Insect Behav. 11: 889-904.

VINSON S.B. \& SCARBOROUGH T.A. 1989: Impact of the imported fire ant on laboratory populations of cotton aphid (Aphis gossypii) predators. Fla. Entomol. 72: 107-111.

VÖLKL W. 1995: Behavioural and morphological adaptations of the coccinellid, Platynaspis luteorubra for exploiting ant- attended resources (Coleoptera: Coccinellidae). J. Insect Behov. 8: 653-670.

VölKL W. \& KRoupa A.S. 1997: Effects of adult mortality risks on parasitoid foraging tactics. Anim. Behav. 54: 349-359

VöLKL W. \& VoHLAND K. 1996: Wax covers in larvae of two Scymnus species: do they enhance coccinellid larval survival? Oecologia 107: 498-503.

WAY M.J. 1963: Mutualism between ants and honeydewproducing Homoptera. Annu. Rev. Entomol. 8: 307-344.

Wellenstern G. 1952: Zur Ernährung der Roten Waldameise (Formica rufa L.). Z. PflKrankh. PflSchutz 59: 430-451.

WheEleR W.M. 1911: An ant-nest coccinellid (Brachyacantha quadripunctata Mels.). J. New York Entomol. Soc. 19: 169-174.

ZAR J.H. 1999: Biostatistical Analysis. 4th edition, Prentice Hall, New Jersey, 931 pp.

Received June 17, 2002; revised September 2, 2002; accepted October 4, 2002 